\title{
Collaborative planning mechanisms in urban megaproject development: the case of Chicago
}

Ana PERIĆ, ETH Zurich, Institute for Spatial and Landscape Development, Zurich, Switzerland; University of Belgrade, Faculty of Architecture, Belgrade, Serbia

Tijana TUFEK-MEMIŠEVIĆ, Candarc LLC, Chicago, United States

Zorica NEDOVIĆ-BUDIĆ, University of Illinois, CUPPA, Chicago, United States

\begin{abstract}
The 'iron-law of megaproject management' relies upon the logic of exception and includes extra budget, special regulations, non-standard organisational structure, questioning of public accountability, and the central role of developers at the expense of the city leaders, planners and citizens. With previous in mind, the crucial question is how to improve collaboration among different interested parties, negotiate diverse interests, and secure transparent planning procedures leading to the outcome that will address many of the initially identified needs. To explore the collaborative mechanisms, we focus on the case of Lincoln Yards, a contemporary urban megaproject development in the central part of Chicago, United States. Using the overview of primary sources (legal and regulatory documents and newspapers articles) and semistructured interviews with the relevant stakeholders, we elucidate the following: 1) the response of professional planners towards the developer's application, i.e., the intention to redevelop the area; 2) the approach applied and values promoted by developers; 3) the strategies used by the local community to protect the local identity and local needs; and 4) the relationship of public officials (aldermen) towards both the local public and investors. Finally, the case provides insights into the lessons learned relevant for the spatial challenges posed by urban megaproject development.
\end{abstract}

\section{Keywords}

urban megaprojects, collaboration, stakeholders, Lincoln Yards, Chicago

\section{Introduction}

Contemporary megaproject development frequently happens on abandoned industrial sites or deprived urban areas - brownfields - usually situated within the inner-city centre, well-connected to the transport nodes, equipped with diverse infrastructural networks, and close to the built urban patterns. New development demands the change of the previous land use and a significant improvement or new construction of both infrastructural grids and the building stock (Fainstein, 2008; Flyvbjerg, 2014). Hence, urban megaprojects are a point of interest to various stakeholders: developers chasing for profit through revitalising the site, citizens tending to protect their local urban identity, and planners and public officials stretched between the ethical norms to secure the public benefits and pressure imposed by financially powerful actors (Del Cerro Santamaria, 2013; Lee, 2012; Flyvbjerg, 2009). 
To illustratively explain the complexity imposed by a megaproject development, Flyvbjerg (2017) defines the "iron-law" of megaprojects based on the logic of exception and including the extra budget, special regulations, non-standard organisational structure, questioning of public accountability, and the central role of developers at the expense of the city leaders, planners, and citizens. Such a management mode of megaproject development as well as physical characteristics of the built environment usually underpinned by 'starchitects' are similar regardless of the specificities of a socio-spatial setting (Ponzini, 2020). However, what differs across the world is the response of both the public and civil sectors towards private-initiated megaproject development. In other words, the extent of the governmental and nongovernmental control over the megaproject development and, consequently, the extent of involvement of different stakeholders varies across transitional societies to welfare states and liberal democracies.

The history of megaproject development in the United States (US) is long, and, accordingly, the main driving forces behind massive development changed over time. The major redevelopment was publicly supported in the 1960s and 1970s due to the US federal public incentive in urban renewal (Fainstein, 2008). The state provided the funding, coordinated the development, and led the implementation (Diaz Orueta and Fainstein, 2008). However, the proliferation of private-initiated urban megaprojects started after the demise of the federal policy in 1974 (Fainstein, 2008; Fisher, 2015; Fisher and Leite, 2018), induced by the global financial crisis. The main management approach of urban megaprojects became a public-private partnership, whilst the public sector shifted its operating mode first to the managerial and later to the entrepreneurial spirit (Fainstein, 2001; Brenner, 2004, 2019). Consequently, various instruments to incentivise private development were introduced.

Contemporary US liberal democracy keeps a strong capitalist flavour. Briefly put, the US social model functions as a neoliberal construct, relying upon the market mentality, understanding government as a business, and, more precisely, using the government as a tool for making business happen (Peck and Theodore, 2019; Brenner and Theodore, 2002). Some of the crucial examples of how megaprojects work in the US advanced capitalist economy are well illustrated in the case of Atlantic Yards (Fainstein, 2008; Petretta, 2020) and Hudson Yards (Fisher, 2015; Fisher and Leite, 2018; Petretta, 2020), both in New York.

Compared to the rest of the US, the Chicago megaprojects are even more complicated due to tight feedback between political and financial power. Chicago has a tradition of nurturing a so-called 'political machine' (Simpson, 2018), which stands for political patronage by the city mayor and aldermen as chiefs of the wards (the main territorial units the City of Chicago administrative area is composed of). More precisely, the local politicians ensure their political power by protecting their electors' interests and guaranteeing their benefits (contracts, jobs, etc.). In return, these electors are considered the 'secure voters' in the election procedure. Throughout the past century, there was only one mayor of Chicago to break this vicious circle of the 'political machine' (Simpson et al., 2020). In recent years, little has changed: local officials are in charge of creating the conditions necessary for channelling international and domestic capital into the local environment (Weber, 2015). Such a provision is coupled with a lack of transparency, exclusivity given to some developers over the others, protecting prime locations for private development, and additional financial burden for local taxpayers (Weber, 2010; Fisher, 2015).

According to the City of Chicago Department of Planning and Development (DPD) overview (DPD, 2021), there are currently seven undergoing megaprojects in the central city part (Fig. 1). The Near South Side hosts three mixed-used projects: "The 78" for the 62-acre area of former railroad property, "Bronzeville Lakefront" for the 48-acre site of a former medical centre, and the "ONE Central" for 32 acres of rail yards. "Obama Presidential Center" proposed as a cultural, economic, and education centre on the 19.3acre site in Jackson Park is intended to revitalise the Chicago South Side. "Chicago Fire Football Club Training Facility" for the 32-acre site in Hanson Park is proposed as a complex sports facility for the Belmont Cragin community. "North Union" is a mixed-use development proposed for 8.1 acres of land 
adjacent to the educational institution on the Near North Side. Finally, the "Lincoln Yards" project targets the redevelopment of 53 acres of former industrial land in the Lincoln Park and West Town community areas. In the following lines, we elucidate the main conditions behind initiating the Lincoln Yards project, the nature of the collaboration, and the main planning outcomes. The concluding remarks point to some of the lessons learned useful for similar challenges posed by the megaproject development.

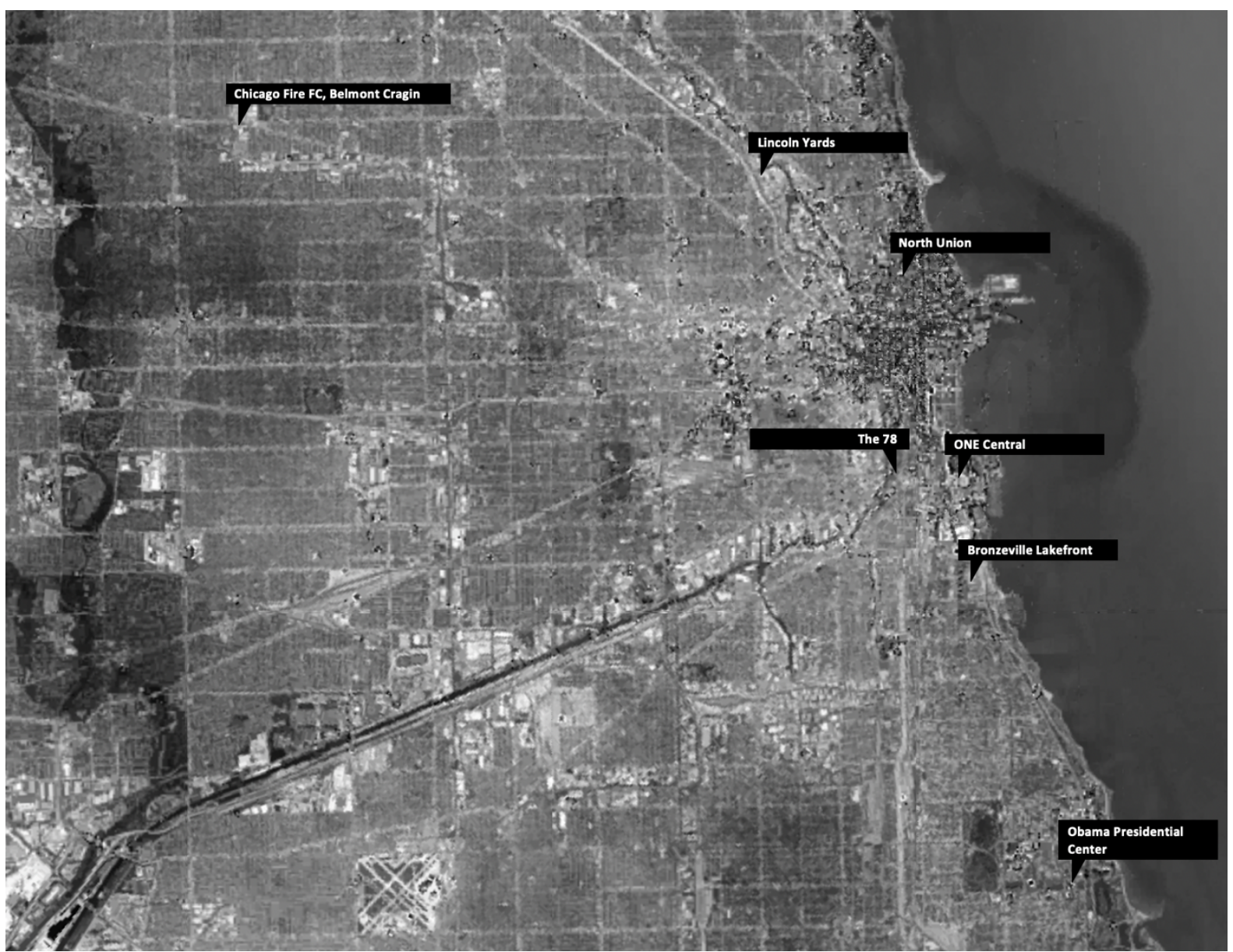

Figure 1. Mega development projects in Chicago. Source: Authors based on DPD, 2021.

\section{Case study: Lincoln Yards}

Lincoln Yards is the first project proposed as aligned to the principles listed in the North Branch Framework Pan (hereinafter framework plan) - addressing the modernisation of the industrial corridor in the central part of Chicago (DPD and CDOT, 2017). The framework plan was an incentive of the then Chicago mayor Rahm Emanuel, in charge from 2011 to 2019, who in 2016 introduced the idea of the redevelopment of several corridors within the city of Chicago. In its essence, the framework plan is a visionary document based on various analyses (mainly economic, transport and environmental) aimed at bettering the existing urban conditions of the corridors' catchment areas. It revolves around three pillars: economic improvement, refurbishment of the current and construction of new transport network, and provision of green and open spaces to improve environmental status. The framework plan contains three main zones, and Lincoln Yards belong to its northern section (Fig. 2). 


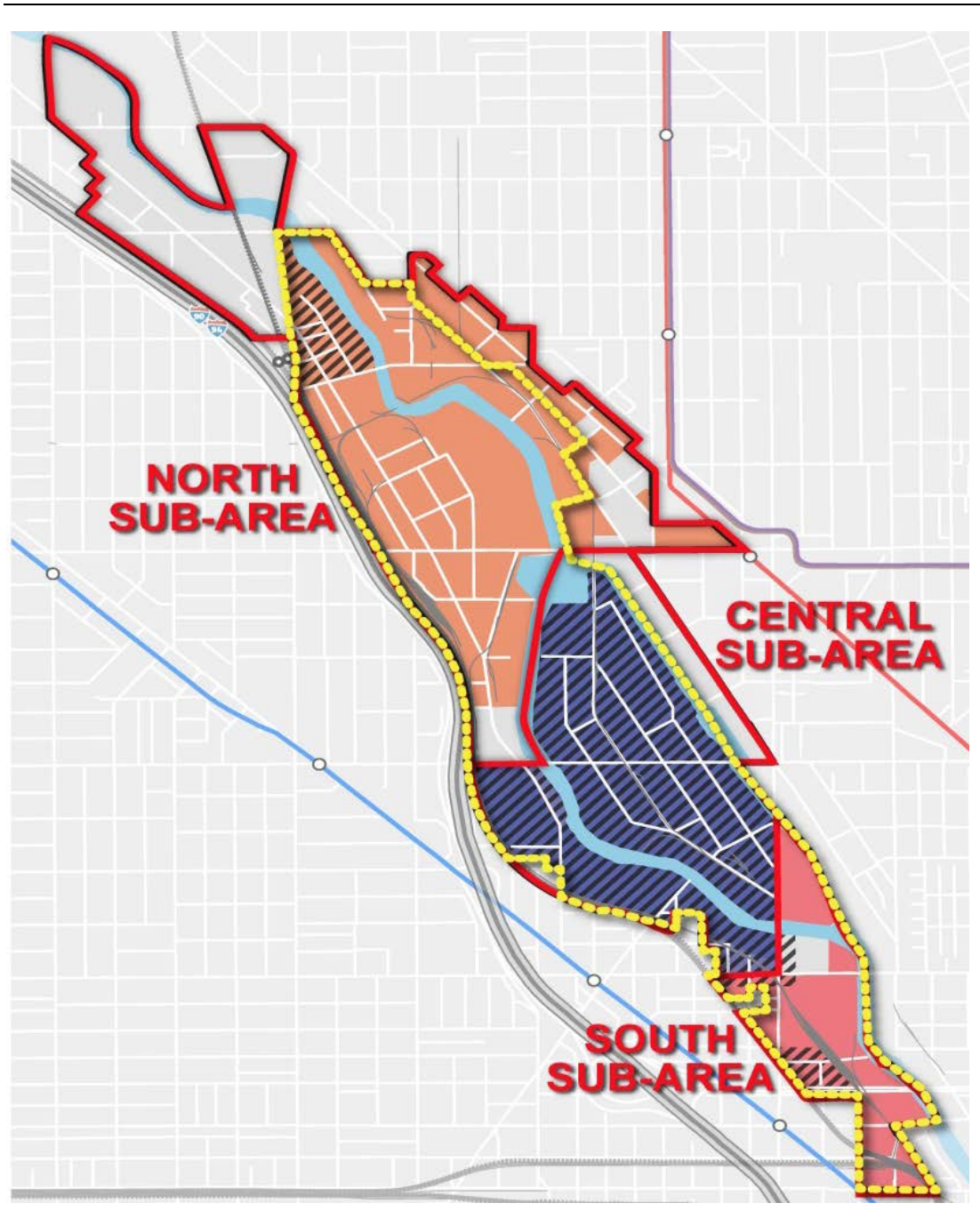

Figure 2. North Branch Framework: Land-Use / Zoning. Source: DPD, 2019b.

In line with the previously mentioned entrepreneurial city spirit, the market conditions intrinsically incentivised the formulation of the framework plan. During the 2010s, due to a change of the global market conditions, e.g., low price of imported raw data, high domestic wage, etc., a vast majority of the industrial enterprises (like steel and tinder companies) decided to terminate their operation, some even after a century-long tradition. In the north part covered by the framework plan, the steel company Finkl Steel shut down its operation in 2013. his was a direct impulse for a private developer - Sterling Bay who started negotiation and bought the company in 2016. Throughout the coming years, the developer continued with acquiring another manufacturer - Fleet, finalised in 2018. The land ownership enabled Sterling Bay to proceed with creating the proposal for a future city landmark area.

The project developer Sterling Bay is a successful company specialized in mix-used urban development, with several references of the refurbished areas in Chicago. The area designated for the future development by the Lincoln Yards project covers a 53-acre area (approx. 22 hectares) in the vicinity of the Chicago downtown ( $7 \mathrm{~km}$ far from the city centre), close to the main express highway leading to the north of the city, and railway corridor connecting northern suburbs to the city centre. The catchment area of the Lincoln Yards project contains a dense public transport network with, though, obsolete hubs. The project area directly covers the waterfront, as this position was crucial for the operation of the previous industrial manufacturers.

The Sterling Bay's proposal (Figs. 3 and 4) considers the recommendations suggested by the framework plan and builds upon the favourable infrastructural conditions of the wider area to include the following: 
improved infrastructural network (new streets to connect the river banks, refurbishment of existing and construction of two new bridges, redevelopment of a junction as well as the nearby public transport station); mix-used development including residential use of 6,000 estimated units, 25 per cent of which devoted to affordable housing, office and retail spaces; and large green and open areas, sports courts and river-walks covering 40 per cent of the entire site area. Additional public benefits include the creation of 23,000 permanent jobs in the project areas, 10,000 construction jobs, with 30 per cent participation by Minority Business Enterprises, and 10 per cent by Women Business Enterprises. The estimated total costs are $\$ 6$ Billion. The project is scheduled for realisation in three phases, starting from the northern part of the project area.

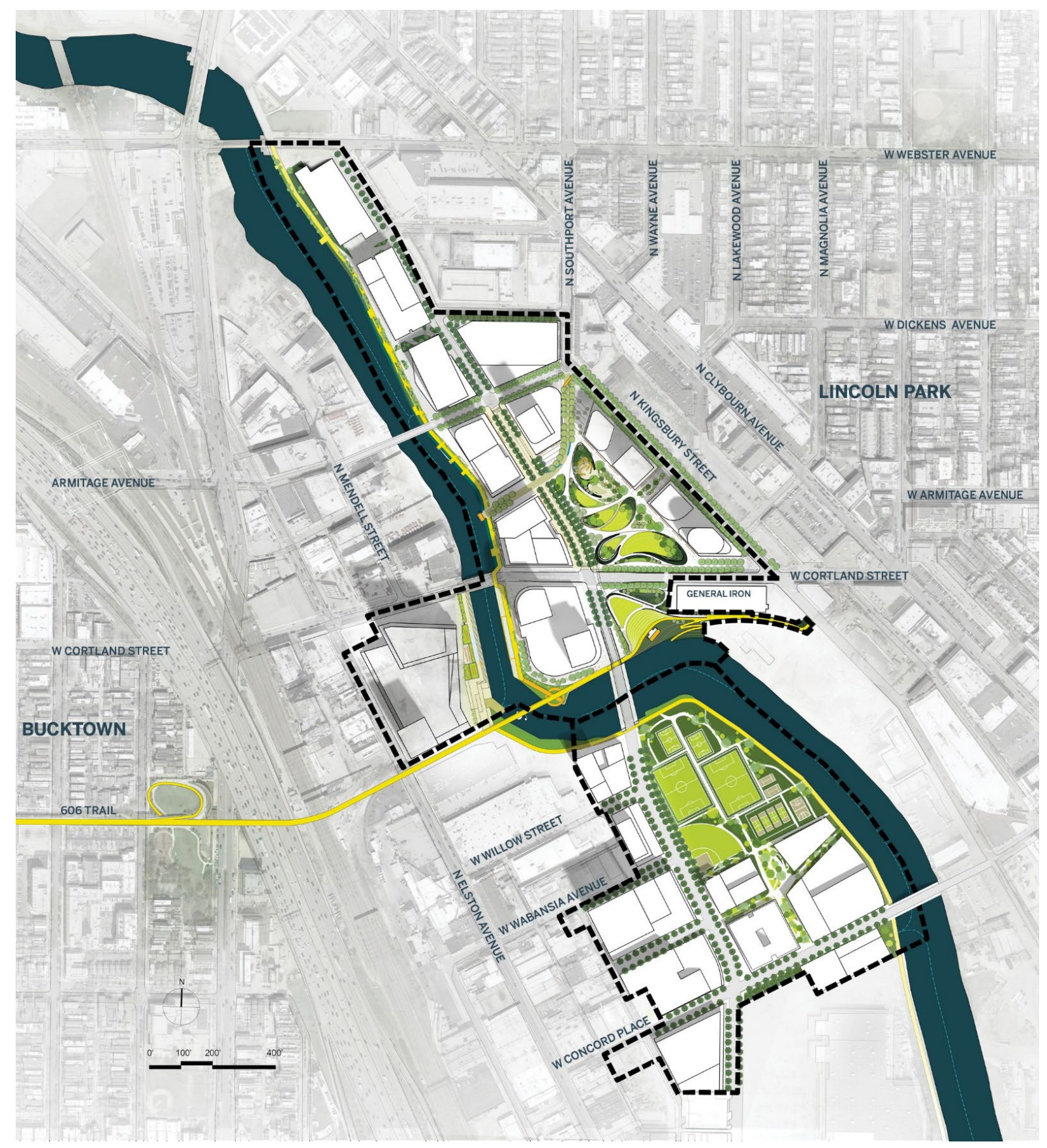

Figure 3. Lincoln Yards: Site Plan. Source: DPD, 2019b. 


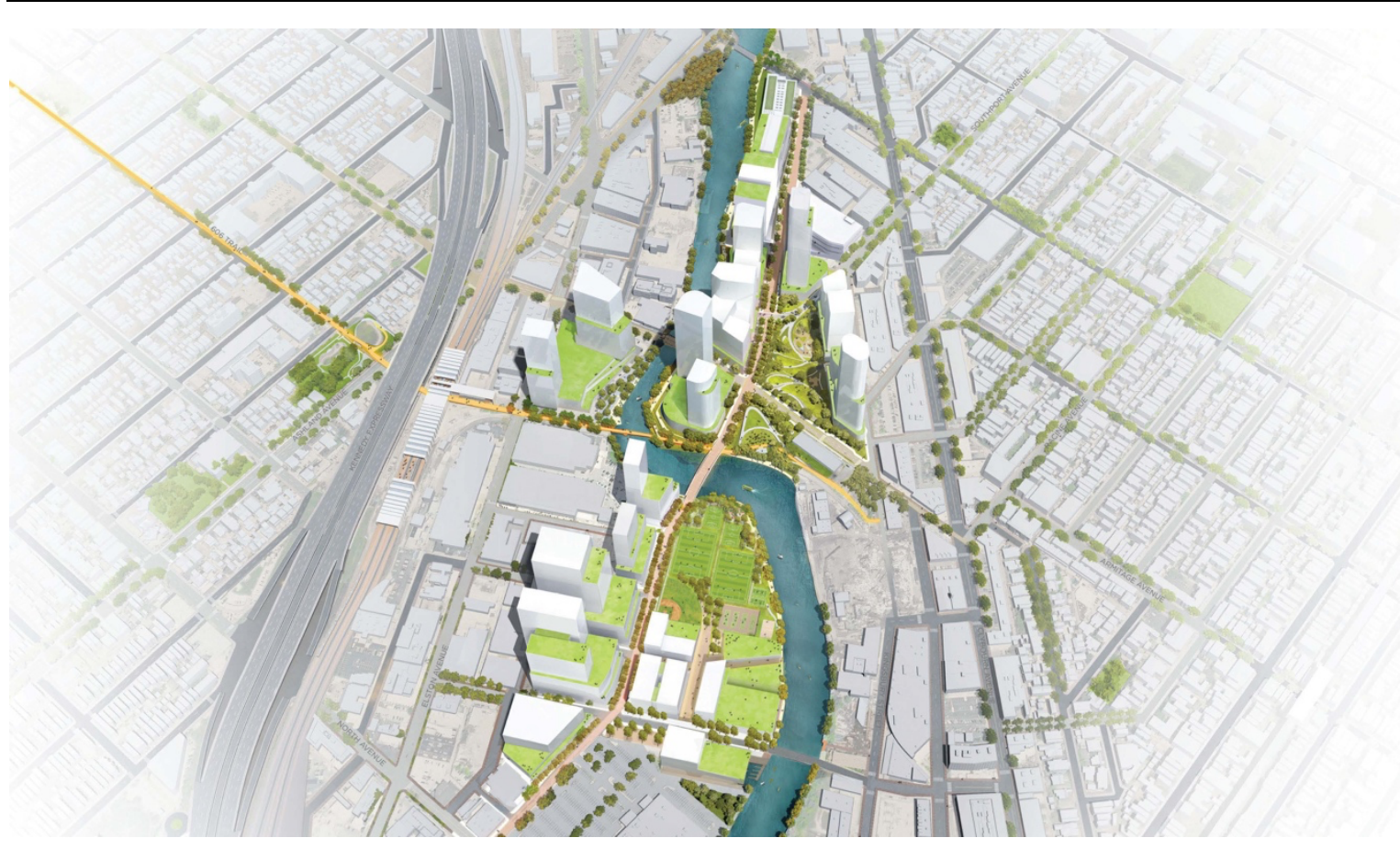

Figure 4. Lincoln Yards: Model. Source: DPD, 2019b.

\section{Lincoln Yards: another typical megaproject development?}

Megaproject developments usually operate as a highly polarised mechanism: on the one hand, developers are backed by tax reliefs and subsidies by the local (city) government, while the general public and, more loudly, local community organisations oppose megaprojects due to questionable social benefits (affordable housing, cultural amenities, green and open areas, newly created jobs assigned to the local population, displacement, etc.). In elucidating the case of Lincoln Yards, we pay particular attention to the following groups of stakeholders: city planners, city officials, developers, and the local community.

The regulatory backup for the Lincoln Yards project was the North Branch Framework Plan. As mentioned, in the absence of more comprehensive planning documentation, the framework plan for the redevelopment of the catchment areas of major transport infrastructure corridors was not part of a broader vision designating the strategic development of the city. Taking the mayoral vision as a reference point, the DPD planners defined the urban design principles as the main guidelines for implementing the vision. As supported by the consultancy firms responsible for developing the graphic material of the framework plan, the DPD planners were not focused on preparing the plan but rather on coordinating the inputs received by different consultants. The planners' coordinative role was particularly emphasised in organising and conducting the procedure of public revision of the framework plan, which overcame the public input as envisioned by the guidelines of the PD review process (DHED, 2012). The review phase lasted between June 2016 and April 2017 and included six public meetings, six neighbourhood meetings, and six 'open houses' hosting more than 800 participants expressing their concerns. Since September 2016, the DPD planners were supported in organising the community meetings by the ward administration (mainly the 2nd ward, as the majority of the Lincoln Yards project covers the area of the 2nd ward). After the initial enthusiasm, the public response became less stark - the last public meeting was attended by only 37 participants out of 900 calls sent (through direct emails, wards' communication, and local media). Nevertheless, the DPD planners consider the participatory planning process successful in attracting the overall large number of interested community organisations and citizens capable of openly addressing their concerns to the general ideas behind the framework plan. According to mayor 
Emanuel's vision, the Chicago Plan Commission adopted the framework plan in May 2017, enabling the developers to proceed with the Lincoln Yards project proposal situated in the northern part of the area covered by the framework plan.

The professionals' role in the process preliminary to the Lincoln Yards project elaboration points to a different power holder than professional expertise. Namely, the framework plan was conceived as a mayoral vision and approved as initially proposed. This can be explained as a long-established tradition of the rubber stamp of the aldermen towards the mayor - which was the case in almost all previous mayor positions except Harold Washington in the 1980s (Simpson et al., 2020). However, mayor Emanuel had also strong external supporters in pursuing his visions. Among Emanuel's mayoral campaign in 2015 were some of the premier regional and, even, national bodies. What is particularly relevant for the case of the Lincoln Yards is the activity of the lawyer company DLA Piper, which was one of the most significant fundraisers of Emanuel's 2015 electoral campaign, donating $\$ 129,000$, while its main activity is legal counselling to major developers (Chase et al., 2015). Whilst preparing the documentation for the Lincoln Yards project, Sterling Bay's main legal advisory office was, and still is, DLA Piper. As a result, the level of public distrust of the initial idea behind the Lincoln Yards project was immense.

Immediate feedback between the highest city officer - mayor Emanuel, and developer - Sterling Bay, elucidates the developer's early property acquisition in 2015, two years before the framework plan adoption. In addition, the developer was chosen without a bidding procedure. In contrast to such an exclusive position in the phase preliminary to the master plan (i.e., PD) elaboration, the developers showed their readiness to exchange with the local population and general public, through a range of different meetings - from small gatherings in the homes of the locals, to large meetings organised by the 2nd ward administration and several community groups (e.g., Wrightwood Neighbors, Sheffield Neighbors). In total, eight meetings and two extensive community surveys (each yielding almost 900 responses) were organised to raise public awareness and provide details on future development. The central role in the phase of master plan public inspection (May 2018 - January 2019) was devoted to the 2nd ward alderman administration, which applied the proactive tailor-made approach to coordinate public hearings, acting as a 'judge' between developers, community organisations, residents, and the general public interested in the Lincoln Yards project.

During the public hearing procedure, the most outstanding achievement was the change of the draft master plan - initially proposing a stadium and a Live Nation concert space. Local community bar owners considered such a proposal in contrast to preserving the local identity and culture of intimate, cosy public places, gathered around the Chicago Independent Venue League (CIVL) and protested against the emerging threat to music venues in the city (Newman, 2019). Although at first sight, it seemed that developers listened to the neighbourhood representatives, some argue that the additional studies proved insufficient transport capacity of the area for receiving a large number of visitors (Newman, 2019). This made the developers change the initial idea on the concert space on the spot. Additional changes to the draft master plan enabled through the citizen feedback supported by the 2 nd ward alderman were an increase of green area (from 12 to almost 21 acres) and removal of one high-rise building. According to the ward administration, developers did not receive any compensation for their 'concessions', which was the sign of Sterling Bay's need to ally with local public authorities as the crucial player in the decisionmaking procedure.

Despite some changes in the draft master plan due to the public engagement, some local representatives claimed that there was not enough time to engage more with the development. The owners of Hideout, the local gathering space with a century-long tradition, pointed out that 'six months flew too fast' (Newman, 2019). Most importantly, the community did not have a chance to induce a fundamental change, as everything seemed to be already decided. This was obvious at two points of a decision-making procedure. Firstly, the session devoted to approving the final master plan by the Plan Commission in 
January 2019 hosted a significant number of neighbourhood residents, community organisations, and the aldermen of the neighbouring wards who expressed their dissatisfaction with the proposed development. The entire meeting lasted 5,5 hours, but the Plan Commission unanimously approved the plan, whilst the minutes of this meeting do not mention a word of the long-lasting debate in the City Hall. Secondly, the TIF (Tax Increment Funding) study was adopted without public inspection by the Chicago Community Development Commission (CDC) in February 2019. This is, ironically, considered a standard approach: though TIF mainly affects ordinary people in the neighbourhood, their voice is not heard in this procedure (Newman, 2019).

The designation of the catchment area of the project site as a TIF area is one of the most controversial subsidies given to the developer. As a US-specific mechanism introduced in Illinois in 1977, TIF still perseveres as the vital instrument for collecting public money for the infrastructural improvement within the TIF area (Weber, 2015). As proposed in the Lincoln Yards TIF study (DPD, 2019a), the city was unable to financially support infrastructural improvements in the project catchment area, so such an incentive was left to Sterling Bay. The developer agreed to upfront investment in the area (\$490 Million), pending reimbursement by the TIF collected money once the infrastructural works are finalised. Apart from this, the investor commits to the following non-reimbursable investments: $\$ 39$ Million into the Affordable Housing Opportunity Fund, \$110 Million to the City of Chicago's Industrial Corridor Fund and North Branch Corridor bonus programme, and $\$ 300$ Million in public infrastructure improvements.

Four issues contribute to the controversy of TIF assigned to the area covered by the Lincoln Yards project. Firstly, if the TIF is assigned to a particular area, that site should be considered blighted. However, the criteria for determining the blighted areas (65 ILCS 5/) refer only to the micro-location (e.g., the exindustrial area currently out of use with deteriorated facilities). However, the catchment area of a microlocation is not considered a relevant criterion. Hence, it is not surprising that TIFs are assigned to the sites on prime locations (close to the city centre and on the waterfront), just as Lincoln Yards. Secondly, a small portion of neighbouring residents will face a tax increase, even though the value of their properties will not rise in the next several years, at least as the basic infrastructural improvements are finalised. The owners of retail and cafes will face a decline in the number of visitors as long as the construction work obstructs their activities to perform to the extent before the construction started. However, according to the former DPD Commissioner Reifman, the entire area will be redeveloped for the benefit of all, as the improved communication network will positively affect the number of people living, working, and visiting the area (Kamin, 2018). Thirdly, the TIF study preparation has been assigned to a private consultancy firm without revision and control by any public body. Such an exclusive procedure poses a threat to the outcome of the TIF arrangements, as they are adopted without an external, critical evaluation. The TIF study is a legally obligatory document for both the City of Chicago and Sterling Bay in the foreseen reimbursement process. Finally, although the study states that reimbursement can be made only for public infrastructure front-end investment, TIF money also includes 2 per cent of economic development (understood as direct support to the developer).

The previously mentioned procedural inconsistencies, and possible conflict of interest, were accompanied by the corruption allegations of the aldermen then in charge of the prominent city committees (Finance Committee and Zoning Committee). That gave hope to the neighbourhood representatives and some aldermen that the procedure of the TIF study approved by the Community Development Commission (involving the representative of the mentioned committees) could have been delayed for adoption (Newman, 2019). Nevertheless, the study was adopted at an extraordinary session of the City Council on April 19, 2019, just two weeks before the election of the new mayor. Sterling Bay got the green light to start the construction works. 


\section{Conclusion}

The development of the Lincoln Yards project fits well into the image of megaproject development: promise on jobs creation, infrastructural improvement, and land remediation and securing green and open space. The assessment of social benefits is more complicated. It depends on the viewpoints of particular stakeholders: residents may oppose park areas to be privately managed, local small entrepreneurs question the heritage protection and preservation of local identity, whilst TIF-opponents address the further segregation between rich and poor Chicago population. However, as the entire process of both the framework plan and master plan for Lincoln Yards preparation involved many diverse participants with different needs, interests, and viewpoints, some interim lessons learned may improve future megaprojects development in Chicago. In its essence, all the lessons learned revolve around various control mechanisms either already applied or suggested for further implementation.

Already applied control mechanisms:

- DPD in charge of controlling the public amenities during the construction phase by demanding the completion of the green and open areas when reaching 50 per cent of the total construction work

- Mayoral establishment of the advisory board (Lincoln Yard Advisory Council) to act as a link between the community needs and developers interests during the project implementation

Control mechanisms under current approval/adoption:

- Limit the 'aldermanic prerogative' by increasing the number of planners in the aldermanic committees

- Improve the public participation in the process of public PD inspection, by introducing additional community meetings, and timely announced public hearing in front of the Plan Commission

Control mechanisms to be applied:

- Diminish tight feedback between city officials (mayor and aldermen) and developers, by more transparent application procedures, and obligatory bidding procedure to enable competition between different developers, to, finally, secure lesser investment into the project by the city

- Minimize a 'dictatorial' position of public officials through inducing term limits for elected local public officials

- Avoid 'conflict of interest' among aldermen by making alderman a full-time job and disable secondary employment, particularly in economic and legal consultancy branches

- Avoid 'conflict of interest' whilst preparing the TIF study by disabling assignment of the TIF study task preparation to a consultancy office by the developer and introducing an additional body (consultancy firm or public office) in charge of the evaluation of the preliminary TIF study

- Improve the planners' skills of facilitation and mediation among numerous interested parties to enable them to explore real need and interest and, consequently, to offer solutions that will genuinely protect common goods

Finally, according to the Planned Development for Lincoln Yards (official ordinance 1439), the key risk lies with the investor. The city's approach is quite reserved:

- The use of TIF will primarily be focused on infrastructure - not private development costs

- Private developers may construct infrastructure on behalf of the City or in partnership with CDOT and will be reimbursed once projects are completed and accepted by the City

- Risk is with development, not the City -TIF is only provided as the increment is generated

- No agreement using TIF funds for infrastructure construction will be made with developers without City Council approval 
Aligned with the previously elaborated need to control megaproject development by various mechanisms, the risk of an urban megaproject is inversely proportional to the size of city government support. In the case of Lincoln Yards, the public support relies only upon the TIF subsidies to the developer, whilst Sterling Bay undertakes all the risks of construction costs and attracting new users. Although the commitment to the project finalisation was expressed not only by the developer but also by public activist groups, it remains open to see if Lincoln Yards will become the new landmark of Chicago.

Cast broadly, to achieve controlled megaproject development means to improve the local political conditions towards acknowledging the more democratic and inclusive practice instead of nurturing the long-term tradition of polarisation between competing economic and community actors.

\section{References}

Brenner, N. (2004) New State Spaces: Urban Governance and Rescaling of Statehood. Oxford: Oxford University Press.

Brenner, N. (2019) New Urban Spaces: Urban Theory and the Scale Question. Oxford: Oxford University Press.

Brenner, N. and Theodore, N. (2002) Spaces of Neoliberalism: Urban Restructuring in North America and Western Europe. Malden: Blackwell.

Chase, J., Coen, J. and Ruthhart, B. (2015) 'Rahm Emanuel counts on big donors, with many getting City Hall benefits', Chicago Tribune, January 30 [online]. Accessed on May 29, 2021, from https://www.chicagotribune.com/news/ct-rahm-emanuel-political-donors-met-20150130story.html.

Del Cerro Santamaria, G. (ed.) (2013) Urban Megaprojects: A Worldwide View. Bingley: Emerald books.

Diaz Orueta, F. and Fainstein, S.S. (2008) 'The New Mega-Projects: Genesis and Impacts', International Journal of Urban and Regional Research, 32(4), 759-767.

DHED (City of Chicago Department of Housing and Economic Development) (2012) Development Manual for Chicago Plan Commission Projects [online]. Accessed on July 4, 2021, from https://www.chicago.gov/content/dam/city/depts/zlup/Planning and Policy/Publications/Devel opment\%20Manual\%20for\%20Plan\%20Commission\%20Projects/Plan Commission Manual FIN AL for web.pdf.

DPD (City of Chicago Department of Planning and Development) (2021) Large Development Projects [online]. Accessed on July 2, 2021, from https://www.chicago.gov/city/en/depts/dcd.html.]

DPD (City of Chicago Department of Planning and Development) (2019a) Cortland and Chicago River Tax Increment Financing / Redevelopment Area Project and Plan. Chicago: City of Chicago.

DPD (City of Chicago Department of Planning and Development). (2019b). Lincoln Yards: Proposed Planned Development (presentation by DPD for Chicago Plan Commission), January 24, 2019. Chicago: City of Chicago.

DPD (City of Chicago Department of Planning and Development) and CDOT (City of Chicago Department of Transportation) (2017) Mayor's Emanuel Industrial Corridor Modernization. North Branch Framework. Chicago: City of Chicago.

Fainstein, S.S. (2001) The city builders. Lawrence: University Press of Kansas.

Fainstein, S.S. (2008) 'Mega-projects in New York, London and Amsterdam', International Journal of Urban and Regional Research, 32(4), 768-785. 
Fisher, B. (2015) The Myth of Self-Financing: The Trade-Offs Behind the Hudson Yards Redevelopment Project (Working Paper Series 2015-4). New York: Schwartz Center for Economic Policy Analysis and Department of Economics, The New School for Social Research.

Fisher, B. and Leite, F. (2018) The Cost of New York City's Hudson Yards Redevelopment Project (Working Paper Series 2018-2). New York: Schwartz Center for Economic Policy Analysis and Department of Economics, The New School for Social Research.

Flyvbjerg, B. (2009) 'Survival of the unfittest: why the worst infrastructure gets build and what can do about it', Oxford Review Economic Policy, 25(3), 344-367.

Flyvbjerg, B. (2014) 'What You Should Know About Megaprojects and Why: An Overview', Project Management Journal, 45(2), 6-19.

Flyvbjerg, B. (2017) 'Introduction: The Iron Law of Megaproject Management' in Flyvbjerg, B. (ed.) The Oxford Handbook of Megaproject Management. Oxford: Oxford University Press, pp. 1-18.

Kamin, B. (2018) 'Lincoln Yards Plan: Too Tall and Out of Place. Slow It Down', Chicago Tribune, December 28 [online]. Accessed on April 30, 2021, from http://graphics.chicagotribune.com/lincoln-yardsreaction-kamin/index.html.

Lee, C.C.M. (2012) The Fourth Typology: Dominant Type and the Idea of the City (Unpublished doctoral dissertation). TU Delft, Delft.

Newman, S. (2019) 'Can Chicago Keep a \$6-Billion Development from Displacing a 100-Seat Music Club?', NextCity, February 11 [online]. Accessed on May 30, 2021, from https://nextcity.org/features/view/can-chicago-keep-a-6-billion-development-from-displacing-a100-seat-club.

Peck, J. and Theodore, N. (2019) 'Still Neoliberalism?', The South Atlantic Quarterly, 118(2), 245-265.

Petretta, D. (2020) The Political Economy of Value Capture: How the Financialization of Hudson Yards Created a Private Rail Line for the Rich (Unpublished doctoral dissertation). Columbia University, New York.

Ponzini D. (2020) Transnational Architecture and Urbanism: Rethinking How Contemporary Cities Plan, Transform, and Learn. London: Routledge.

Simpson, D. (2018) Rogues, Rebels, and Rubber Stamps: The Politics of the Chicago City Council, 1863 to the Present. Boca Raton: Routledge.

Simpson, D., Mixon, C. and Mouritsen, M. (eds.) (2020) Twenty-First Century Chicago. San Diego: Cognella.

Wang, L. and Hoch, C. (2013) 'Pragmatic rational planning: Comparing Shanghai and Chicago', Planning Theory, 12(4), 369-390.

Weber, R. (2010) 'Selling City Futures: The Financialization of Urban Redevelopment Policy', Economic Geography, 86(3), 251-274.

Weber, R. (2015) From Boom to Bubble: How Finance Built the New Chicago. Chicago: The University of Chicago Press. 